\title{
HUBUNGAN TINGKAT STATUS GIZI WANITA MENOPAUSE DENGAN PERUBAHAN FISIK PADA MASA MENOPAUSE KOTA SEMARANG
}

\author{
CORRELATION BETWEEN WOMEN'S NUTRITION STATUS OF MENOPAUSE WITH \\ PHYSICAL CHANGES OF MENOPAUSE IN SEMARANG CITY
}

\author{
Dewi Elliana), Anita Murniwati') \\ ${ }^{12)}$ Akademi Kebidanan Abdi Husada Semarang \\ Akademi Kebidanan Abdi Husada Semarang \\ Email : elliana_dewi@yahoo.com
}

\begin{abstract}
ABSTRAK
Menopause terjadi akibat dari penurunan produksi hormon estrogen yang dihasilkan oleh kelenjar endokirin dimana pada usia sekitar 45-55 tahun ditandai dengan keluhan haid yang mulai tidak teratur. Berdasarkan studi pendahuluan terhadap 10 wanita yang berumur 45-55 tahun di Kelurahan Bendanduwur Kecamatan Gajahmungkur kota Semarang, didapatkan bahwa sebagian besar telah mengalami perubahan fisik menopause. Kejadian perubahan fisik yang terjadi dipengaruhi oleh banyak faktor diantaranya adalah status gizi yang kurang. Penelitian ini secara umum mengetahui hubungan tingkat status gizi dengan perubahan-perubahan fisik pada masa menopause di Kelurahan Bendan Duwur Kecamatan Gajahmungkur Kota Semarang. Jenis Penelitian ini adalah penelitian kuantitatif dengan pendekatan cross sectional. Populasi dalam penelitian ini adalah 55 wanita menopause dengan karakter yaitu memiliki tingkat umur 45-55 Tahun. Pengambilan sampel dalam penelitian ini menggunakan metode non probability sampling dengan Tehnik purposive sampling. Hasil penelitian menunjukkan bahwa sebagian besar responden di Kelurahan bendan duwur Kecamatan Gajahmungkur kota Semarang memiliki status gizi kurang dengan menggunakan uji chi squre didapatkan hasil 11,062 dengan p value sebesar 0,001, Nilai p value lebih kecil dari 0,005. Hal ini berarti responden yang memiliki status gizi kurang cenderung proporsi mengalami perubahan fisik masa menopause lebih besar dibandingkan responden yang memiliki status gizi baik hubungan antara status gizi dengan perubahan fisik pada masa menopause secara statistik bermakna. Kesimpulan ada hubungan yang bermakna antara status gizi dengan perubahan fisik pada masa menopause. Oleh karena itu sebaiknya tenaga kesehatan khususnya bidan diharapkan untuk memberikan penyuluhan tentang pentingnya gizi berkaitan dengan perubahan fisik pada masa menopause.
\end{abstract}

Kata kunci : status gizi,perubahan fisik pada masa menopause

\begin{abstract}
Menopause occurs as a result of decreased production of estrogen hormone produced by the endokirin glands where at the age of about 45-55 years characterized by irregular menstrual complaints. Based on a preliminary study of 10 women aged 45-55 years in Bendanduwur sub-district Gajahmungkur sub-district of Semarang city, it was found that most have undergone a physical change of menopause. The occurrence of physical changes that occur is influenced by many factors including the lack of nutritional status. This research generally know the correlation of nutritional status level with physical changes at menopause in Bendan Duwur Sub-District Gajahmungkur Sub-district Semarang City. This research type is quantitative research with cross sectional approach. The population in this study were all women in Bendanduwur sub-district Gajahmungkur Kota Semarang a number of 55 menopausal women with character that has age 45-55 years old. Sampling in this research using non probability sampling method with purposive sampling technique. The result of this research shows that most of respondent in bendan duwur sub district Gajahmungkur city of Semarang have less nutritional status by using chi squre test got result 11,062 with p value 0,001, $p$ value less than 0,005. Respondents who have nutritional status is less likely to proportion experiencing menopausal physical changes greater than respondents who have good nutritional status relationship between nutritional status with physical changes in menopause is statistically significant. There is a significant relationship between nutritional status and physical changes during menopause. Therefore, health workers, especially midwives should be advised to provide counseling about the importance of nutrition associated with physical changes during menopause.
\end{abstract}

Keywords: nutritional status, physical changes during menopause 


\section{PENDAHULUAN}

Pembangunan nasional yang bertujuan mewujudkan masyarakat adil dan makmur berdasarkan Pancasila dan UUD 1945, telah menghasilkan kondisi sosial masyarakat yang makin membaik dan usia harapan hidup makin meningkat, menurut laporan WHO tahun 2000 usia harapan hidup adalah 67,8 tahun dan pada tahun 2020-2025 mendatang diperkirakan menjadi 73,6 tahun (Bandiyah, 2009).

Data dari Indonesia jumlah usia lanjut meningkat sebesar 7,4 \% sekitar 15,3 juta jiwa. Proyeksi biro statistik tahun 2005-2010 jumlah usia lanjut sebesar 8,5\% (Depkes RI 2006). Pada tahun 2000 jumlah usia lanjut meningkat sebesar $9,99 \%$ dari seluruh penduduk Indonesia (22.277.700 jiwa) dengan umur harapan hidup 65-70 tahun. Pada tahun 2020 akan meningkat menjadi 11,09\% (29.120.000) dengan usia harapan hidup 70-75 tahun (Bandiyah, 2009). Pada tahun 2000 jumlah penduduk Indonesia mencapai 203,46 juta orang yang terdiri 101,81 juta perempuan dan diperkirakan telah memasuki usia menopause, sebanyak 15,5 juta orang $(15,2 \%)$ pada tahun 2020 diperkirakan jumlah perempuan yang hidup dengan usia menopause adalah 30,3 juta (Baziad, 2003). Data jumlah penduduk yang ada di Indonesia pada tahun 2007 sebanyak 235.56 juta orang yang terdiri dari 102,23 juta jiwa perempuan, yang memasuki usia 45 tahun ke atas 15.625.241 jiwa. Pada tahun 2008 jumlah penduduk sebanyak 253,35 juta orang yang terdiri dari 131,35 juta perempuan yang memasuki usia 45 tahun ke atas 15.635.241 jiwa. Pada tahun 2009 jumlah penduduk sebanyak 242,25 juta jiwa yang terdiri dari 121,05 juta perempuan yang memasuki usia 45 tahun ke atas 15.655.231 jiwa (Badan Pusat Statistika, Semarang, 2008). Data jumlah penduduk yang ada di Provinsi Jawa Tengah pada tahun 2007 jumlah penduduk 32.380.279 jiwa yang terdiri 16.416.157 jiwa perempuan, memasuki usia 45 tahun ke atas sebanyak 7.859.625 jiwa. pada tahun 2008 sebanyak 32.626 .390 jiwa yang terdiri dari 16.434.095 jiwa perempuan memasuki usia 45 tahun ke atas sebanyak 8.565.123 jiwa. dan tahun 2009 jumlah penduduk 33.657 .390 terdiri perempuan 17.286.145 jiwa, dan 8.795.092 jiwa yang telah memasuki usia diatas 45 tahun (Badan Pusat Statistika, Provinsi Jawa Tengah, 2008).

Data jumlah penduduk pada tahun 2007 di kota Semarang jumlah penduduk 1.480 .433 jiwa yang terdiri dari 732.065 jiwa perempuan dan memasuki usia $45 \mathrm{ke}$ atas sebanyak 599.703 jiwa. pada tahun 2008 jumlah penduduk sebanyak 1.480 .630 jiwa yang terdiri 732.065 jiwa perempuan dan yang memasuki usia 45 tahun ke atas sebanyak 615.703 jiwa (Badan Pusat Statistika, Kota Semarang, 2008).

Jumlah seluruh penduduk kelurahan Kecamatan Gajahmungkur tahun 2010 sebanyak 61.668 jiwa yang dikelompokkan menurut umur yang terdiri 30.726 jiwa perempuan dan jumlah wanita yang memasuki usia 45-55 tahun sebanyak 12.402 jiwa. Kelurahan Sampangan jumlah wanita sebanyak 4.647 jiwa yang berusia 45 tahun keatas sebanyak 611 jiwa, Bendan duwur jumlah wanita sebanyak 1.555jiwa yang berusia 45tahun keatas sebanyak 187 jiwa,kelurahan Karang rejo jumlah wanita 3.681 jiwa yang berusia 45tahun keatas sebanyak 523jiwa,kelurahan Gajahmungkur jumlah wanita sebanyak 7.226 jiwa yang berusia 45tahun keatas sebanyak 1001jiwa,kelurahan Bendan ngisor jumlah wanita sebanyak 3.840 jiwa yang berusia 45tahun keatas sebanyak 458 jiwa,kelurahan Petompon jumlah wanita sebanyak 4.091 jiwa yang berusia 45tahun keatas sebanyak 492,kelurahan Bendungan jumlah wanita sebanyak 2.395 jiwa yang berusia 45tahun keatas sebanyak 319 jiwa,kelurahan Lempongsari jumlah wanita sebanyak 3.425 jiwa yang berusia 45 tahun keatas sebanyak 454 jiwa. 
Menopause adalah berhentinya siklus menstruasi yang berlangsung selama klimakterium pada wanita (Baziad, 2003). Dimana dalam perjalanan seorang wanita yang mencapai umur sekitar 45 tahun mengalami penuaan indung telur sehingga tidak sanggup memenuhi hormon estrogen, sehingga terjadi perubahan siklus menstruasi dan sistem hormonal mengalami kemunduran (Manuaba,2001). Bagi seorang wanita memasuki usia menopause timbul beberapa keluhan seperti perubahan fisik, peningkatan jumlah kerapuhan tulang (Baziad, 2003).

Walaupun tidak dialami oleh semua perempuan secara umum gejala yang ditimbulkan oleh menopause adalah menstruasi tidak teratur, hot flushes (semburan panas, perubahan emosi) selain gejala -gejala tersebut, pada wanita menopause akan mengalami peningkatan jumlah kerapuhan tulang (osteoporosis) serta kejadian penyakit jantung dan pembuluh darah. Kerapuhan tulang menyebabkan wanita menopause sering mengalami peningkatan patah tulang. Sedangkan penyakit kardiovaskular yang terjadi adalah penyakit jantung koroner. Selain itu angka kanker payudara maupun endometrium turut juga meningkatkan pada masa ini (Baziad, 2003).

Selain itu terjadinya menopause dipengaruhi oleh faktor-faktor genetik, faktorfaktor sosial ekonomi dan status gizi. Pada wanita yang mengalami kembar dizigot, wanita dengan siklus haid memendek, wanita nulipara, wanita dengan diabetes melitus, wanita perokok berat, wanita kurang gizi, wanita vegetarian dan pada wanita yang hidup pada ketinggian $>4000 \mathrm{~m}$ akan mengalami menopause lebih awal (Baziad, 2003).

Status gizi merupakan kesehatan yang dihasilkan oleh keseimbangan antara kebutuhan dan masukan nutrient. Kesiapan menghadapi menopause menurut Dini dalam Erna (2004) mengkonsumsi makanan bergizi yaitu mengkonsumsi makanan dengan gizi seimbang. Pemenuhan gizi memadai sangat membantu menghambat berbagai dampak negatif menopause terhadap kinerja otak, mencegah kulit kering dan berbagai penyakit lainnya, serta mencegah menopause datang lebih awal. Selain status gizi dan perubahan fisik yang perlu diperhatikan pada masa menopause tingkat pengetahuan juga penting karena pengetahuan merupakan hasil dari tahu, dan ini terjadi setelah orang melakukan penginderaan terhadap suatu objek (Notoatmodjo 2003).

\section{Data dari Puskesmas}

Pegandan, berdasarkan demografi jumlah penduduk menurut kelompok umur di Kelurahan Bendan Duwur dengan jumlah penduduk keseluruhan 3.244 jiwa, yang terdiri dari perempuan 1.600 jiwa, dengan jumlah wanita yang memasuki usia 45-55 tahun sebanyak 235 orang dan memiliki status gizi kurang sebanyak 33 orang dengan keluhan perubahan fisik, Kelurahan Bendan Ngisor dengan jumlah penduduk sebanyak 7.548 jiwa dengan jumlah wanitanya sebanyak 3.840 jiwa dengan jumlah wanita yang memasuki usia 45-55 sebanyak 449 jiwa dan masih memiliki status gizi kurang sebanyak 29 orang dengan keluhan perubahan fisik, Kelurahan Karangrejo dengan jumlah penduduk 7.402 jiwa dengan jumlah wanita 3.681 jiwa, memasuki usia 45-55 tahun 450 jiwa, dan memiliki status gizi kurang 30 orang dengan keluhan perubahan fisik pada masa menopause. Dari data di atas menunjukan status gizi masih rendah dengan keluhan perubahan fisik, berdasarkan data diatas kelurahan yang masih memiliki status gizi dan perubahan fisik kurang dengan keluhan perubahan kulit, perubahan sistem jantung, perubahan liang senggama dan kerapuhan tulang adalah Kelurahan Bendan Duwur (Puskesmas Pegandan, 2009).

Berdasarkan study pendahuluan yang dilakukan pada wanita menopause yang berusia 45-55 tahun pada bulan Oktober 2010 di Kelurahan Bendan Duwur Kecamatan Gajahmungkur Kota Semarang didapatkan 7 dari 10 orang wanita menopause (70\%) 
berstatus gizi baik dan 2 orang wanita menopause $(20 \%)$ telah mengalami perubahan fisik menopause seperti ketidakteraturan haid, gejolak panas, kekeringan vagina, perubahan kulit dan berat badan, buah dada menipis menjadi lembek dan menggantung, dan 5 dari 10 orang wanita menopause $(50 \%)$ berstatus gizi kurang dan 2 orang wanita menopause $(20 \%)$ telah mengalami perubahan fisik pada menopause seperti ketidakteraturan siklus haid, gejolak panas, kekeringan vagina, perubahan kulit dan berat badan, buah dada menipis dan menjadi lembek.5 orang wanita menopause $(50 \%)$ berstatus gizi rendah dan 6 orang wanita menopause $(60 \%)$ telah mengalami perubahan fisik pada menopause seperti ketidakteraturan siklus haid. Gejolak panas kekeringan vagina, perubahan kulit dan berat badan, buah dada menipis dan menjadi lembek.

Berdasarkan latar belakang diatas maka penulis tertarik untuk mengambil judul "Hubungan Tingkat Status Gizi Wanita Menopause Dengan Perubahan Fisik Pada Masa Menopause di Kelurahan Bendan Duwur Kecamatan Gajahmungkur Semarang".

\section{METODE PENELITIAN}

Jenis penelitian ini adalah penelitian kuantitatif yaitu jenis penelitian yang menekankan analisisnya pada data-data numerical (angka) yang diolah dengan metode stastistika yang bersifat survey analitik dan didasarkan pada penggunaan kuesioner sebagai instrumen. Adapun metode penelitian yang digunakan yaitu cross sectional,dengan populasi wanita menopause usia 45-55 di Kelurahan Bendan Duwur Kecamatan Gajah Mungkur Semarang sejumlah 55 responden dengan sampel penelitian 36 responden.

\section{HASIL DAN PEMBAHASAN}

\section{A. Tingkat Status Gizi}

Distribusi frekuensi responden berdasarkan tingkat status gizi dalam penelitian ini sebagai berikut.

\begin{tabular}{lcc}
$\begin{array}{c}\text { Tabel 1. Distribusi } \\
\text { berdasarkan Tingkat Status Gizi }\end{array}$ & Frekuensi & Responden \\
\hline $\begin{array}{c}\text { Tingkat Status } \\
\text { Gizi }\end{array}$ & $\mathrm{n}$ & $\%$ \\
\hline Kurang & 5 & 69,4 \\
\hline Baik & 1 & 30,6 \\
\hline Total & 6 & 100 \\
\hline
\end{tabular}

Berdasarkan hasil penelitian diperoleh hasil sebagian besar responden pada tingkat status gizi kurang sebanyak $25(69,4 \%)$ sedangkan yang baik hanya sebanyak $11(30,6 \%)$ responden. Hal ini sesuai dengan pendapat system lumbung pangan, 2008 tingkat status gizi responden yang kurang dapat disebabkan oleh produk makan yang dikunsumsi yang kurang, konsumsi makanan atau kebiasaan makan yang tidak seimbang, keadaan ekonomi yang kurang maupun kurangnya pengetahuan para responden. Karena halhal tersebut diatas maka tingkat status gizi para responden sebagian besar termasuk dalam kategori kurang. Hal ini disebabkan bahwa factor-faktor yang mempengaruhi gizi akan berinteraksi satu sama lain sehingga berimplikasi kepada status gizi seseorang. Status gizi seimbang sangat penting terutama bagi pertumbuhan, perkembangan, kesehatan dan kesejahteraan manusia. Pendapat lain juga disampaikan oleh (Supariasa, 2002) Status gizi adalah keadaan gizi seseorang yang menggambarkan apa yang dikonsumsinya dalam waktu yang cukup lama, dimana keadaan gizi ini merupakan akibat dari keseimbangan antara konsumsi dengan penyerapan zat gizi dan penggunaan zat-zat tersebut atau keadaan fisiologik akibat tersedianya zat gizi dalam seluler tubuh 
Sesui dengan hasil penelitian dan pendapat pakar hal ini memberikan gambaran bahwa tingkat status gizi responden yang kurang tersebut dapat disebabkan oleh ketidakseimbangan zat yang dikonsumsi dengan kebutuhan gizi pada para lansia yang sedang mengalami menopause.

\section{B. Perubahan Fisik Masa Menopause}

Distribusi frekuensi responden berdasarkan perubahan fisik masa menopause responden dapat dilihat dalam tabel berikut.

Tabel 2. Distribusi Frekuensi Responden berdasarkan Perubahan Fisik masa Menopause

\begin{tabular}{ccc}
\hline Perubahan Fisik & $\mathrm{n}$ & $\%$ \\
\hline Tidak mengalami & 12 & 33,3 \\
Mengalami & 24 & 66,7 \\
\hline Total & 36 & 100 \\
\hline
\end{tabular}

Berdasarkan hasil penelitian diperoleh bahwa sebagian besar responden mengalami perubahan fisik masa menopause sebanyak $24 \quad(63,7 \%)$ dibandingkan dengan responden yang tidak mengalami perubahan fisik masa menopause sebanyak 12 responden $(33,3 \%)$. Hal ini sesuai dengan pendapat Manuaba, 1999 bahwa Perubahan fisik yang dialami pada masa menopause seperti ketidakteraturan siklus haid, gejolak panas, kekeringan vagina, perubahan pada kulit ,dan berat badan, gelisah dan sukar tidur, perubahan tulang, buah dada menipis menjadi lembek dan menggantung, sulit terangsang, jantung berdebar-debar serta sakit kepala. Dimana pada usia 45 - 65 tersebut akan terjadi perubahan masa baya yaitu masa premenopause, fase menopause dan fase pascamenopause.

Pendapat lain juga disampaikan baziad, 2003 bahwa Menopause adalah berhentinya haid secara permanen setelah aktifnya ovarium, sebagai akibat berkurangnya hormone estrogen, dimana masa menopause terjadi pada usia $45-65$ tahun (Baziad, 2003). Sebagai salah satu tanda-tanda terjadinya masa menopause adalah keluhan terjadinya perubahan fisik pada seseorang wanita.

Sesuai hasil penelitian dan berbagai pendapat pakar membrikan gambaran bahwa sebagian besar responden mengalami terjadinya perubahan fisik masa menopause.

C. Hubungan tingkat status gizi dengan perubahan-perubahan fisik pada masa menopause di Kelurahan Bendan Duwur Kecamatan Gajahmungkur Kota Semarang

Tabel 3. Hubungan tingkat status gizi dengan perubahan-perubahan fisik pada masa menopause di Kelurahan Bendan Duwur Kecamatan Gajahmungkur Kota Semarang

\begin{tabular}{|c|c|c|c|c|c|c|}
\hline \multirow{3}{*}{$\begin{array}{c}\text { Status } \\
\text { Gizi }\end{array}$} & \multicolumn{4}{|c|}{ Perubahan Fisik } & \multirow{3}{*}{$\begin{array}{c}\text { Total } \\
\mathrm{n}\end{array}$} & \multirow{3}{*}{$\%$} \\
\hline & \multicolumn{2}{|c|}{$\begin{array}{c}\text { Tidak } \\
\text { mengalam } \\
\text { i }\end{array}$} & \multicolumn{2}{|c|}{$\begin{array}{c}\text { Mengalam } \\
\mathrm{i}\end{array}$} & & \\
\hline & $\mathrm{n}$ & $\%$ & $\mathrm{n}$ & $\%$ & & \\
\hline Kurang & 4 & 16,0 & 21 & 84,0 & 25 & 100 \\
\hline Baik & 8 & 72,7 & 3 & 27,3 & 11 & 100 \\
\hline Total & 12 & 33,3 & 24 & 66,7 & 36 & $\begin{array}{c}100 . \\
0\end{array}$ \\
\hline
\end{tabular}

Hasil penelitian Responden dengan responden dengan status gizi kurang sebanyak 25 responden, sebanyak $84,0 \%$ responden mengalami perubahan fisik masa menopause sedangkan yang tidak mengalami $4 \quad(16,0 \%)$ responden. Responden dengan tingkat status gizi baik yaitu 11 responden, yang tidak mengalami perubahan fisik masa menopause $8 \quad(72,7 \%)$ responden sedangkan $27,3 \%$ responden mengalami perubahan fisik masa menopause. Berdasarkan hasil analisis diperoleh bahwa ada hubungan tingkat status gizi 
dengan perubahan-perubahan fisik pada masa menopause di Kelurahan Bendan Duwur Kecamatan Gajahmungkur Kota Semarang, dengan menggunakan uji Chi Square didapatkan nilai $\mathrm{p}$ value sebesar $=$ 0.001 ( $\mathrm{p}$ value $<0.05$. Karena nilai $p$ value lebih kecil dari 0.05 dengan demikian $\mathrm{Ha}$ diterima, yang berarti ada hubungan tingkat status gizi dengan perubahan-perubahan fisik pada masa menopause di Kelurahan Bendan Duwur Kecamatan Gajahmungkur Kota Semarang.

Hal ini sesuai pendapat manuaba, 1999 bahwa Perubahan pola makan yang menjurus pada makanan yang banyak mengandung karbohidrat akan menimbulkan perubahan kerja usus halus dan besar, sehingga dapat menurunkan estrogen yang dapat menyebabkan perubahan kerja usus menjadi lambat. Perubahan fisik yang dialami pada masa menopause seperti ketidakteraturan siklus haid, gejolak panas, kekeringan vagina, perubahan pada kulit dan berat badan, gelisah dan sukar tidur, perubahan tulang, buah dada menipis menjadi lembek dan menggantung, sulit terangsang, jantung berdebar - debar serta sakit kepala. Dimana pada usia 45 - 65 tersebut akan terjadi perubahan masa baya yaitu masa premenopause, fase menopause dan fase pascamenopause.

Hal ini menggambarkan bahwa dengan status gizi yang kurang akan dapat meningkatnya terjadinya perubahan fisik pada wanita masa menopause, karena dengan keadaan status gizi yang kurang asuhan gizi yang dibutuhkan oleh tubuh kurang seimbang sehingga menyebabkan terjadinya perubahan fisik semakin cepat.

\section{KESIMPULAN}

1. Sebagian besar responden pada tingkat status gizi kurang sebanyak $25(69,4 \%)$ responden
2. Sebagian besar responden mengalami perubahan fisik masa menopause sebanyak $24(63,7 \%)$ responden.

3. Ada hubungan tingkat status gizi dengan perubahan-perubahan fisik pada masa menopause di Kelurahan Bendan Duwur Kecamatan Gajahmungkur Kota Semarang, didapatkan hasil Chi square sebesar 11,062 dengan $p$ value sebesar 0,001

\section{DAFTAR PUSTAKA}

Alimul, H. 2007. Metode Penelitian Kebidanan Dan Teknik Analisis Data. Jakarta: Salemba Medika

Almatsir, S. 2001. Prinsip Dasar Ilmu Gizi. Jakarta: Gramedia Pustaka

Arikunto. 2006. Prosedur Penelitian Suatu Pendekatan Praktis. Jakarta: Rineka Cipta

Arisman. 2004. Gizi Dalam Daur Kehidupan. Jakarta: EGC

Azwar , S. 2007. Metode Penelitian. Yogyakarta. Pustaka Pelajar

Badan Pusat Statistik. 2008. Proyeksi Penduduk Indonesia (Indonesia Populasi Projection) 2000-2025. Jakarta: Badan Pusat Statistik

Proyeksi penduduk propinsi Jawa Tengah: Jakarta: Badan Pusat Statistik

Proyeksi Penduduk Propinsi Kota Semarang: Jakarta: Badan Pusat Statistik

Bandiyah. 2009. Lanjut Usia dan Keperawatan Gerontik. Yogyakarta: Nuha Medika

Baziad, A. 2003. Menopause dan Andrepause. Jakarta: Yayasan Bina Pustaka

Budiarto, S. 2002. Biostatistika untuk Kedokteran dan Kesehatan Masyarakat. Jakarta: EGC 
Depkes RI. 2002. Pedoman Pengelolaan Kegiatan Kesehatan Di Kelompok Usia Lanjut. Jakarta: Depkes RI 2006. Pedoman Kemitraan Lintas Sektor dalam Pembinaan Lanjut Usia: Jakarta: Depkes RI

Francin.Erna.2004.Gizi Dalam Kesehatan Reproduksi.Jakarta: EGC

Lipi. 1998. Risalah Widya Karya Pangan dan Gizi VI. Jakarta

Manuaba, I.B.G. 2001 Memahami Kesehatan Wanita. Jakarta: EGC

Notoatmodjo. 2005. Metode Penelitian Kesehatan. Jakarta: Rineka cipta
Putri,A. 2009. Tetap Sehat Diusia Lanjut.Yogyakarta:Genius Publisher Sistem Lumbung Pangan (http// www.Pustaka .ut.ac.id).18 Desmber 2010

Sugiyono. 2004. Statistika Untuk Penelitian. Bandung: Alfabeta

Supariasa. I. Dewa Nyoman. 2002. Penilaian Status Gizi. Jakarta: EGC

Wirakusumah. 2003. Tips dan Solusi Gizi Untuk Tetap Sehat Cantik dan Bahagia di Masa Menopause Dengan Terapi Estrogen Alami. Jakarta: Gramedia 